\title{
Exploitation of Resistant Sources to Phytophthora capsici Leon. from Genetic Stocks of Black Pepper (Piper nigrum L.)
}

\author{
K.M. Prakash ${ }^{1}$, R.S. Bhai ${ }^{2}$, J. Jiji ${ }^{1}$, K.V. Saji ${ }^{2}$, V.S. Sujatha ${ }^{1}$ and A.V. Santhoshkumar ${ }^{3}$ \\ ${ }^{1}$ College of Horticulture, Vellanikkara-680656, Kerala Agricultural University, \\ Thrissur, Kerala, India \\ ${ }^{2}$ Indian Institute of Spices Research Marikunnu P. O., Calicut - 673 012, Kerala, India \\ ${ }^{3}$ College of Forestry, Vellanikkara-680656, Kerala Agricultural University, Thrissur, \\ Kerala, India
}

*Corresponding author

\section{A B S T R A C T}

\section{Keywords}

Germplasm accessions, Black pepper, Phytophthora capsic, Piper nigrum, Resistance, Screening

Article Info

Accepted: 12 April 2019 Available Online: 10 May 2019
Intensive screening of black pepper germplasm through artificial inoculation was done at ICAR-Indian Institute of Spices Research, Kozhikode, (Kerala, India) to locate sources of resistance against Phytophthora foot rot incited by Phytophthora capsici Leon. adopting conventional stem and leaf inoculation procedure. The intact stem and leaf of 3-4 leaf stage rooted plants were inoculated and incubated for $72 \mathrm{~h}$ at a temperature of $25-28^{\circ} \mathrm{C}$ with a relative humidity of $80-90 \%$ for development of symptoms. The degree of resistance was rated based on the mean disease severity index (DSI) of leaf, stem and depth of penetration. Based on the mean DSI, the accessions were scored. Among the 20 accessions evaluated, none of them showed complete resistance to $P$. capsici infection. However, the accession 7259 showed moderate resistance with an overall mean DSI of $39.44 \%$. Accession 7254 was found to be highly susceptible with a DSI of $91.66 \%$ followed by variety Panniyur5 (check) with mean DSI of $87.78 \%$.

\section{Introduction}

Foot rot caused by Phytophthora capsici Leon. is the most devastating malady of black pepper (Piper nigrum L.) in India and other countries of production affecting black pepper plantations and commercial black pepper nurseries. On a global scale, foot rot alone caused an annual crop loss of \$ 4.5-7.5 million (De Waard, 1979). In Kerala, crop loss by vine death due to foot rot was estimated to the range of $3.4-9.4 \%$ (Anandaraj et al., 1989). Lack of $P$. capsici resistant varieties/cultivars, is a great barrier in disease management in many producing countries worldwide (Nguyen, 2015). Growing resistant cultivars along with promising traits such as yield would be a viable strategy to tackle this disease. The screening for resistance against Phytophthora 
infecting black pepper was started since 1979 in India at the Indian Institute of Spices Research (ICAR-IISR), Kozhikode. ICARIISR is endowed with the largest collection of black pepper germplasm in the country with more than 3000 collections including wild accessions, local types and land races. Sarma and Nambiar (1979) designed a rapid screening technique for identifying resistant sources of black pepper using root inoculation technique. Later root inoculation technique was restricted to the screening of seedling progenies. Considering the main site of infection as collar region, a stem inoculation technique was standardized by them for screening rooted cuttings (Sarma et al., 1982). Based on this technique, after several rounds of screening and field evaluation, an open pollinated progeny of Perambramundi was identified and released as IISR Shakti. Since aerial infection is manifested as foliar infection, resistance of the plants can also be assessed taking into consideration, the reaction of the leaf to $P$. capsici infection. So the objective of the present study was to screen germplasm accessions of black pepper to locate source of resistance to P. capsici using aerial inoculation procedure with an aim to cull out accessions having multiple traits for yield along with disease resistance.

\section{Materials and Methods}

\section{Plant material}

The germplasm accessions of black pepper maintained at ICAR-IISR germplasm were utilized for the Screening purpose. Initially fifty accessions were selected for multiple trait evaluation of which 30 accession were rejected based on natural foot rot incidence. The remaining twenty accessions that escaped infection during the previous year of evaluation were subjected for artificial inoculation to locate Phytophthora resistance (Table 1). The twenty accessions were multiplied by serpentine method. The rooted plants of each accession, raised by serpentine method was transplanted to polythene bags of $21 \mathrm{~cm} \times 15 \mathrm{~cm}$ size and grown up to 3 months for 3-4 leaf stage. These plants were used for screening. Screening was undertaken at ICAR-IISR, Kozhikode (Kerala) during 2018 South-West Monsoon period (June - August) . The screening was repeated thrice with 5 plants per accession.

\section{Phytophthora capsici inoculum}

The isolates of $P$. capsici (05-06) maintained in the Phytophthora repository at ICAR-IISR, Kozhikode was used for screening purpose. The isolate was sub cultured in Carrot agar and grown for $72 \mathrm{~h}$ day night period for inoculation.

\section{Inoculation}

For screening stem, the rooted plants of 3-4 leaf stage was inoculated by making an injury with the sharp edge of a needle at the centre of the third internode from the tip of the stem (Plate 1). Mycelial plug of $3 \mathrm{~mm}$ size cut from the growing edge of $72 \mathrm{~h}$ old culture of $P$. capsici. was placed on the point of injury and a sterile wet cotton pad was placed over it and tied with a polythene strip to keep the inoculum in place without drying.

The inoculated plants were incubated for $72 \mathrm{~h}$ in green house maintained at a temperature of $25-28^{\circ} \mathrm{C}$ and $\mathrm{RH} 80-90 \%$. After $72 \mathrm{~h}$, the cotton pad was removed and the external lesion length was measured using a scale and scored on a $0-4$ scale as $0=$ no lesion, $1=1$ $5 \mathrm{~mm}$ lesion, $2=6-20 \mathrm{~mm}, 3=21-30 \mathrm{~mm}$ and $4=>30 \mathrm{~mm}$ lesion length. Then the stem was split open longitudinally and the depth of penetration (index) was assessed visually by scoring the accessions on a 0 - 4 scale. The ratings (index) are: $0=$ no penetration, $1=$ up to $25 \%$ penetration, $2=25 \%-50 \%$ 
penetration, $3=50-75 \%$ penetration and 4 $=>75 \%$ penetration. Five rooted cuttings were screened per accession in each replication and the average score was taken (Eikemo et al., 2003).

\section{Leaf inoculation}

Simultaneous with stem inoculation, the third or fourth leaf of the intact plant from the top was inoculated by placing inoculums plug of $3 \mathrm{~mm}$ size taken as above. The inoculum plug was placed on the lower surface of the leaf without injury (Plate 2).

A sterile wet cotton strip was placed over the inoculum and kept in position by wrapping with a polythene strip around. The inoculated plants (plate 3) were incubated for $72 \mathrm{~h}$ at a temperature of $24-25 \circ \mathrm{C}$ with relative humidity of $80-90 \%$. After $72 \mathrm{~h}$ of incubation, the leaf lesion diameter was measured and scored on a 0 - 4 scale as $0=$ no lesion, $\mathrm{I}=1-5 \mathrm{~mm}$ lesion, $2=6-10 \mathrm{~mm}$ lesion, $3=11-15 \mathrm{~mm}$ lesion and $4 \Rightarrow 15 \mathrm{~mm}$ lesion. The leaf lesion diameter, stem lesion length and depth of penetration were analyzed statistically. From the lesion scorings, the disease severity index (DSI) was calculated for leaf and stem using the formula of Kim et al., 2000.

Disease severity index $(\mathrm{DSI})=$

(Sum of ratings of each plant)

---------------------------------- X 100

(Maximum score $\mathrm{x}$ No. of plants)

Final rating of accessions was made based on overall mean DSI (DSI) of leaf, stem and depth of penetration. The overall mean DSI for each accession was worked out to categorize the accessions as $<30 \%=$ resistant (R), 31- 40\% as Moderately Resistant (MR) and $>40 \%$ as Susceptible (S).

\section{Results and Discussion}

Varying degrees of resistance was noticed in screening and the reactions were significantly different among the accessions (Tables 1, 2, 3 and Plate 4). Among the 20 accessions subjected for screening, none of them showed complete resistance to $P$. capsici. Only one accession viz.7259 has shown moderate resistance with an overall mean DSI of 39.44 for characters like stem lesion, depth of penetration index and leaf lesion. It is a promising accession worth further field level evaluation. As seen in Table 2, the lowest DSI value (23.33) was observed for depth of penetration followed by stem lesion length $((33.33 \mathrm{~mm})$ and leaf lesion diameter $(61.67 \%)$. In the screening maximum DSI was observed for 7289 for leaf lesion diameter $(100 \%)$ in $72 \mathrm{~h}$ followed by P5 and Acc. 7254 for stem lesion length (91.67\%) and depth of penetration $(95.0 \%)$. As per the Table 3 also, the overall mean DSI was highest $(91.67 \%)$ for the Acc. 7254. The lowest (39.44) for accession 7259. In a screening study of pepper germplasm, Bhai et al., (2007) reported that one hybrid (Acc.1375), two wild accessions (Accs.3160 and 3260) and four Kottanadan selections (2466, 2471, 2515 and 2433) were promising with a disease index of 1 with no external lesion after stem inoculation. Forty one black pepper cultivars and 73 wild Piper species were screened against $P$. palmivora adopting root dip inoculation technique and found Narayakodi, Kalluvalli, Uthiaramkotta and Balankotta with low percentage of infection (Sarma et al., 1982). None of the wild species in these screening showed any level of resistance. Divya and Sharda, (2014) reported Panniyur-5, Aribally and Karimunda as resistant (0\%) among the 9 varieties/cultivars tested by root inoculation using soil drenching with zoospore suspension, whereas Panniyur1, Panniyur- 3, Panniyur-4, Panniyur-6 and Panniyur-7 were highly susceptible. In 
another study Mammootty et al., (2008) found that the black pepper genotypes Karimunda I, Karimunda II, Panniyur-1 Panniyur-2, Panniyur-3, Panniyur-4, Panniyur-5, Panniyur-6 and Panniyur- 7 showed 89.3\%, 90\%, 88.7\%, 68\%, 90\%, $95.3 \%, 55 \%, 90.7 \%$ and $85.3 \%$ of leaf infection respectively and $73.7 \%, 62.2 \%$, $67.2 \%, 67.8 \%, 67.3 \%, 73.7 \%, 31.2 \%, 60 \%$ and $59.3 \%$ respectively for mortality by inoculation of zoospore and culture discs of
Phytophthora capsici on leaves, stems and roots. However in the present study also Panniyur 5 showed high susceptibility (mean DSI - 87.78\%) to foot rot fungus through the stem and leaf inoculation trials (Table 3). The promising identified line among the accessions (Acc.7259) may be assayed for further root infection by the pathogen and evaluated in the field for confirmation of resistance.

Table.1 Passport details of 50 accessions of black pepper used for the study

\begin{tabular}{|l|l|l|l|l|l|}
\hline SI No. & Acc.No. & IC No & Place of collection & District & Latitude/longitude \\
\hline $\mathbf{1}$ & 7239 & 598889 & Kayapoil & Kannur & $11.86 .07 / 75.41 .40$ \\
\hline $\mathbf{2}$ & 7240 & 598890 & Kayapoil & Kannur & $11.86 .07 / 75.41 .40$ \\
\hline $\mathbf{3}$ & 7241 & 598891 & Kayapoil & Kannur & $11.86 .07 / 75.41 .40$ \\
\hline $\mathbf{4}$ & 7243 & 598893 & Kakkara & Kannur & $11.86 .07 / 75.41 .40$ \\
\hline $\mathbf{5}$ & 7249 & 598899 & Ammankad & Kannur & $11.86 .07 / 75.41 .40$ \\
\hline $\mathbf{6}$ & 7252 & 598902 & Oduvally & Kannur & $11.86 .07 / 75.41 .40$ \\
\hline $\mathbf{7}$ & 7254 & 598903 & Naduvil & Kannur & $12.12 .25 / 75.49 .42$ \\
\hline $\mathbf{8}$ & 7255 & 598904 & Naduvil & Kannur & $12.12 .25 / 75.49 .42$ \\
\hline $\mathbf{9}$ & 7258 & 598905 & Mandalam & Kannur & $12.07 .35 / 75.30 .16$ \\
\hline $\mathbf{1 0}$ & 7259 & 598906 & Mandalam & Kannur & $12.07 .35 / 75.30 .16$ \\
\hline $\mathbf{1 1}$ & 7262 & 598909 & Mandalam & Kannur & $12.07 .35 / 75.30 .16$ \\
\hline $\mathbf{1 2}$ & 7264 & 598911 & Mandalam & Kannur & $12.07 .35 / 75.30 .16$ \\
\hline $\mathbf{1 3}$ & 7237 & 598888 & Kakkara & Kannur & $11.86 .07 / 75.41 .40$ \\
\hline $\mathbf{1 4}$ & 7232 & 598883 & Vellora & Kannur & $12.92 .25 / 79.13 .90$ \\
\hline $\mathbf{1 5}$ & 7215 & 598869 & Mayyil-Velam & Kannur & $11.99 .36 / 75.45 .09$ \\
\hline $\mathbf{1 6}$ & 7211 & 598866 & Meenmutty & Wynadu & $11.72 .56 / 76.11 .04$ \\
\hline $\mathbf{1 7}$ & 7276 & 598920 & Kattippara & Kozhikode & $12.51 .03 / 75.20 .14$ \\
\hline $\mathbf{1 8}$ & 7277 & 598921 & Kattippara & Kozhikode & $12.51 .03 / 75.20 .14$ \\
\hline $\mathbf{1 9}$ & 7283 & 598927 & Kattippara & Kozhikode & $12.51 .03 / 75.20 .14$ \\
\hline $\mathbf{2 0}$ & 7285 & 598929 & Kodencherry & Kozhikode & $11.40 .70 / 75.98 .76$ \\
\hline $\mathbf{2 1}$ & 7286 & 598930 & Kodencherry & Kozhikode & $11.40 .70 / 75.98 .76$ \\
\hline $\mathbf{2 2}$ & 7289 & 598933 & Koodathai & Kozhikode & $11.39 .93 / 75.95 .60$ \\
\hline & & & & & \\
\hline
\end{tabular}




\begin{tabular}{|l|l|l|l|l|l|}
\hline $\mathbf{2 3}$ & 7293 & 598936 & Koodathai & Kozhikode & $11.39 .93 / 75.95 .60$ \\
\hline $\mathbf{2 4}$ & 7219 & 598872 & Mayyil-Velam & Kannur & $11.99 .36 / 75.45 .09$ \\
\hline $\mathbf{2 5}$ & 7221 & 598874 & Chapparakkunnu & Kannur & $11.86 .07 / 75.41 .40$ \\
\hline $\mathbf{2 6}$ & 7222 & 598875 & Chapparakkunnu & Kannur & $11.86 .07 / 75.41 .40$ \\
\hline $\mathbf{2 7}$ & 7229 & 598880 & Vellora & Kannur & $12.92 .25 / 79.13 .90$ \\
\hline $\mathbf{2 8}$ & 7251 & 598901 & Ammankad & Kannur & $11.86 .07 / 75.41 .40$ \\
\hline $\mathbf{2 9}$ & 7260 & 598907 & Mandalam & Kannur & $12.07 .35 / 75.30 .16$ \\
\hline $\mathbf{3 0}$ & 7236 & 598887 & Kakkara & Kannur & $11.86 .07 / 75.41 .40$ \\
\hline $\mathbf{3 1}$ & 7230 & 598881 & Vellora & Kannur & $12.92 .25 / 79.13 .90$ \\
\hline $\mathbf{3 2}$ & 7225 & 598877 & Chapparakkunnu & Kannur & $11.86 .07 / 75.41 .40$ \\
\hline $\mathbf{3 3}$ & 7220 & 598873 & Mayyil-Velam & Kannur & $11.99 .36 / 75.45 .09$ \\
\hline $\mathbf{3 4}$ & 7288 & 598932 & Koodathai & Kozhikode & $11.39 .93 / 75.95 .60$ \\
\hline $\mathbf{3 5}$ & 7295 & 598938 & Kodencherry & Kozhikode & $11.40 .70 / 75.98 .76$ \\
\hline $\mathbf{3 6}$ & 7296 & 598939 & Kodencherry & Kozhikode & $11.40 .70 / 75.98 .76$ \\
\hline $\mathbf{3 7}$ & 7297 & 598940 & Norramthodu & Kozhikode & $11.23 .41 / 75.79 .55$ \\
\hline $\mathbf{3 8}$ & 7298 & 598941 & Norramthodu & Kozhikode & $11.23 .41 / 75.79 .55$ \\
\hline $\mathbf{3 9}$ & 7344 & 598984 & $\begin{array}{l}\text { Nariampara- } \\
\text { Kattappana }\end{array}$ & Idukki & $9.66 .43 / 77.09 .74$ \\
\hline $\mathbf{4 0}$ & 7302 & 598945 & Pallickal & Malappuram & $11.04 .16 / 76.07 .97$ \\
\hline $\mathbf{4 1}$ & 7305 & 598948 & Pallickal & Malappuram & $11.14 .29 / 75.92 .20$ \\
\hline $\mathbf{4 2}$ & 7306 & 598949 & Pallickal & Malappuram & $11.14 .29 / 75.92 .20$ \\
\hline $\mathbf{4 3}$ & 7309 & 598952 & Anangapara-Pallickal & Malappuram & $11.14 .29 / 75.92 .20$ \\
\hline $\mathbf{4 4}$ & 7358 & 598997 & $\begin{array}{l}\text { Konginikadavu- } \\
\text { Kattappana }\end{array}$ & Idukki & $9.84 .75 / 76.98 .09$ \\
\hline $\mathbf{4 5}$ & 7325 & 598967 & Vettom- Tirur & Malappuram & $10.90 .07 / 75.89 .71$ \\
\hline $\mathbf{4 6}$ & 7339 & 598979 & $\begin{array}{l}\text { Nariampara- } \\
\text { Kattappana }\end{array}$ & Idukki & $9.66 .43 / 77.09 .74$ \\
\hline $\mathbf{4 7}$ & 7385 & 599024 & Santhigram-Irattayar & Idukki & $9.84 .75 / 76.98 .09$ \\
\hline $\mathbf{4 8}$ & 7386 & 599025 & Santhigram-Irattayar & Idukki & $9.84 .75 / 76.98 .09$ \\
\hline $\mathbf{4 9}$ & 7387 & 599026 & Santhigram-Irattayar & Idukki & $9.84 .75 / 76.98 .09$ \\
\hline $\mathbf{5 0}$ & 7352 & 598992 & Kanjiyar- & Idukki & $9.84 .75 / 76.98 .09$ \\
\hline & & & & & \\
\hline & & & & & \\
\hline
\end{tabular}


Table.2 Reaction of 20 selected black pepper accessions to Phytophthora infection

\begin{tabular}{|c|c|c|c|c|}
\hline Sl. No & Acc No & $\begin{array}{l}\text { Stem lesion } \\
\text { length DSI (\%) }\end{array}$ & $\begin{array}{l}\text { Depth of } \\
\text { penetration } \\
\text { DSI }(\%)\end{array}$ & $\begin{array}{l}\text { Leaf lesion } \\
\text { diameter DSI (\%) }\end{array}$ \\
\hline 1 & 7249 & 31.67 & 43.33 & 61.67 \\
\hline 2 & 7240 & 50.00 & 25.00 & 80.00 \\
\hline 3 & 7221 & 43.33 & 38.33 & 75.00 \\
\hline 4 & 7215 & 53.33 & 56.67 & 81.67 \\
\hline 5 & 7276 & 31.67 & 20.00 & 81.67 \\
\hline 6 & 7211 & 56.67 & 46.67 & 96.67 \\
\hline 7 & 7232 & 41.67 & 46.67 & 81.67 \\
\hline 8 & 7219 & 43.33 & 30.00 & 88.33 \\
\hline 9 & 7255 & 35.00 & 30.00 & 80.00 \\
\hline 10 & 7229 & 40.00 & 43.33 & 86.67 \\
\hline 11 & 7286 & 41.67 & 55.00 & 90.00 \\
\hline 12 & 7254 & 91.67 & 95.00 & 88.33 \\
\hline 13 & 7243 & 78.33 & 78.33 & 98.33 \\
\hline 14 & 7289 & 73.33 & 81.67 & 100.00 \\
\hline 15 & 7293 & 58.33 & 43.33 & 95.00 \\
\hline 16 & 7259 & 33.33 & 23.33 & 61.67 \\
\hline 17 & 7222 & 31.67 & 58.33 & 96.67 \\
\hline 18 & 7241 & 55.00 & 63.33 & 73.33 \\
\hline 19 & 7285 & 45.00 & 56.67 & 80.00 \\
\hline 20 & 7252 & 55.00 & 28.33 & 70.00 \\
\hline 21 & P5 & 76.67 & 86.67 & 100.00 \\
\hline Mean & & 50.79 & 50.00 & 84.13 \\
\hline CD & @5\% & 14.38 & 17.15 & 14.04 \\
\hline $\mathbf{F}$ & & $S$ & $S$ & $S$ \\
\hline
\end{tabular}


Table.3 Rating of black pepper accessions to foot rot disease on the basis of overall mean disease severity index

\begin{tabular}{|c|c|c|c|}
\hline SI. no & $\begin{array}{l}\text { Accession } \\
\text { Number }\end{array}$ & $\begin{array}{l}\text { Overall Mean Disease } \\
\text { Severity Index } \\
\text { (OMDSI) }\end{array}$ & Rating of accession \\
\hline 1 & 7249 & 45.56 & $\mathrm{~S}$ \\
\hline 2 & 7240 & 51.67 & $\mathrm{~S}$ \\
\hline 3 & 7221 & 52.22 & $S$ \\
\hline 4 & 7215 & 63.89 & S \\
\hline 5 & 7276 & 44.44 & $\mathrm{~S}$ \\
\hline 6 & 7211 & 66.67 & $S$ \\
\hline 7 & 7232 & 61.67 & $S$ \\
\hline 8 & 7219 & 53.88 & S \\
\hline 9 & 7255 & 48.33 & $S$ \\
\hline 10 & 7229 & 56.65 & $S$ \\
\hline 11 & 7286 & 62.22 & $S$ \\
\hline 12 & 7254 & 91.66 & $\mathrm{~S}$ \\
\hline 13 & 7243 & 84.99 & $S$ \\
\hline 14 & 7289 & 85 & $\mathrm{~S}$ \\
\hline 15 & 7293 & 65.55 & $S$ \\
\hline 16 & 7259 & 39.44 & MR \\
\hline 17 & 7222 & 62.22 & $\mathrm{~S}$ \\
\hline 18 & 7241 & 63.88 & S \\
\hline 19 & 7285 & 60.55 & $S$ \\
\hline 20 & 7252 & 51.11 & $S$ \\
\hline 21 & P5 & 87.78 & $S$ \\
\hline
\end{tabular}

Plate.1 Stem inoculation of black pepper accession for reaction to $P$. capsici

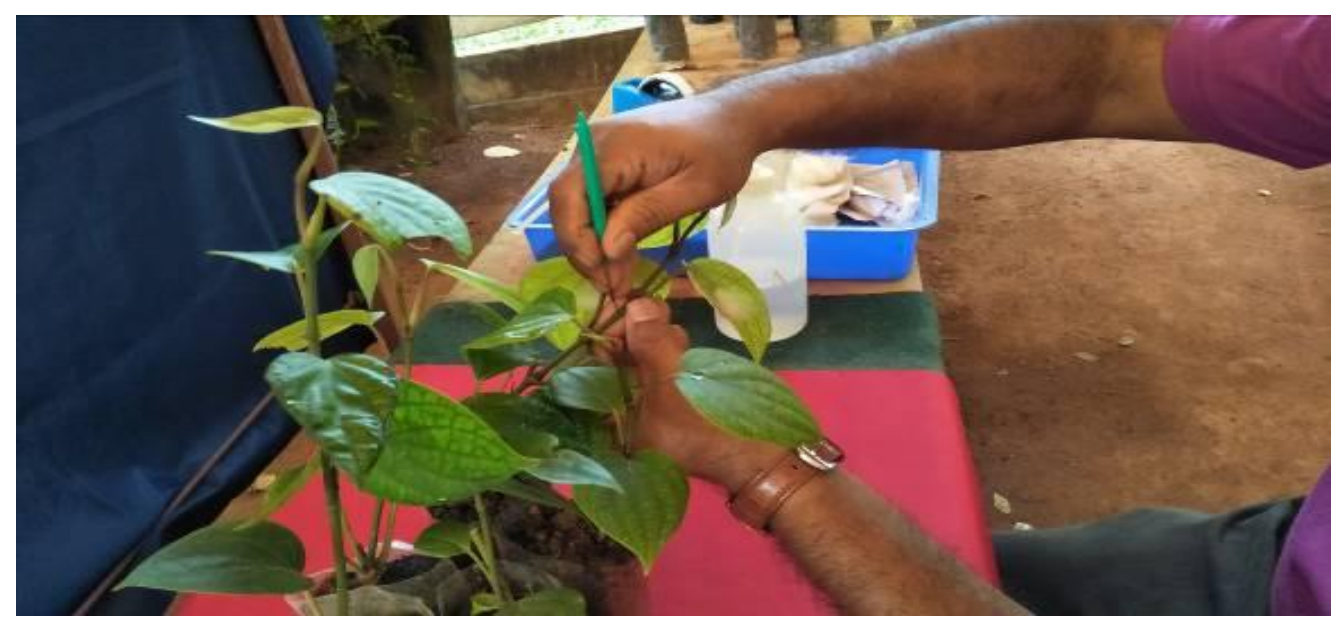


Plate.2 Leaf inoculation of black pepper accession for reaction to $P$. capsici

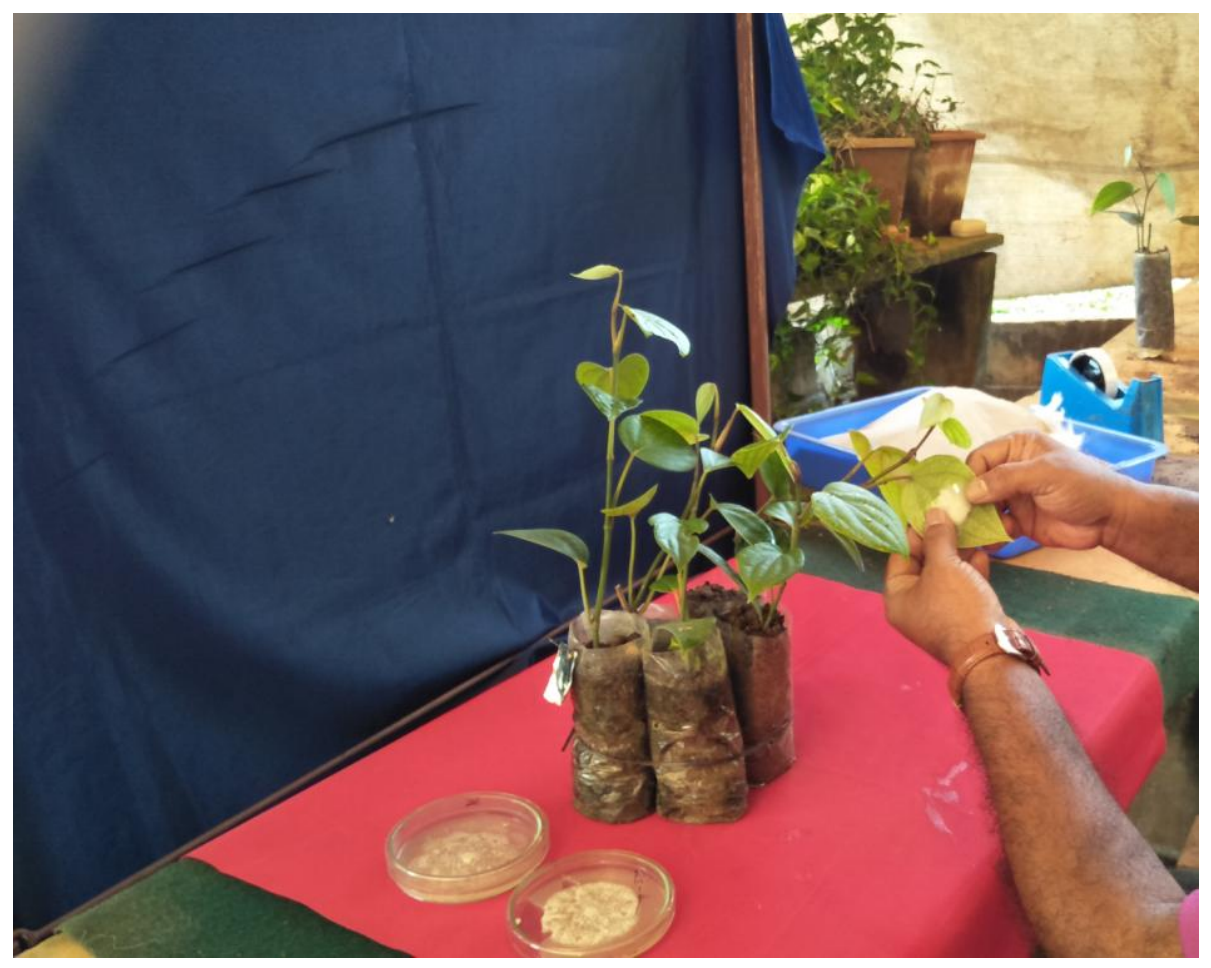

Plate.3 Black pepper accession after stem and leaf inoculation

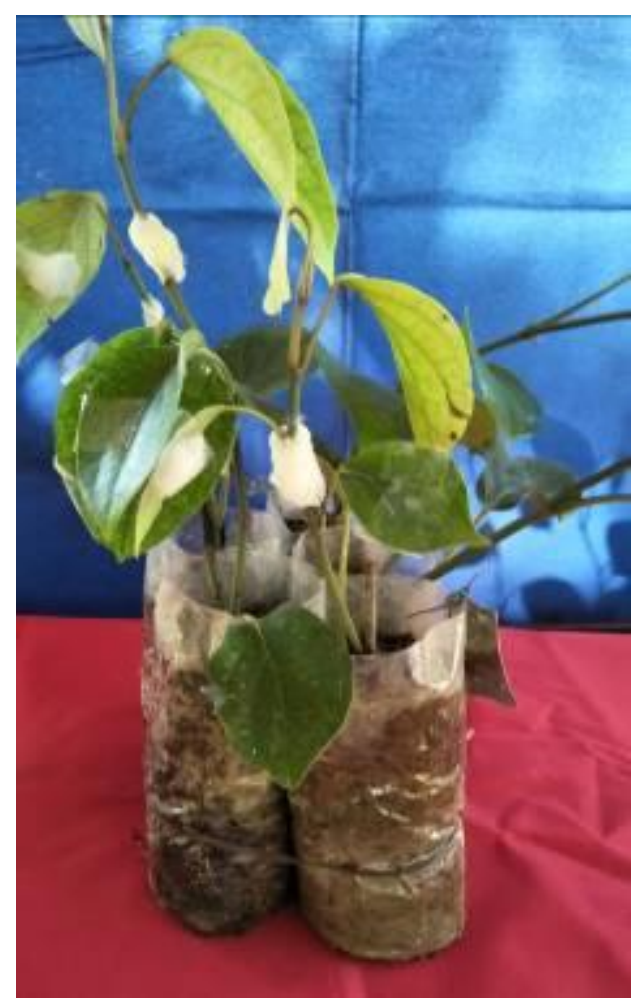


Plate.4 Reaction of few black pepper accessions to P.capsici inoculation

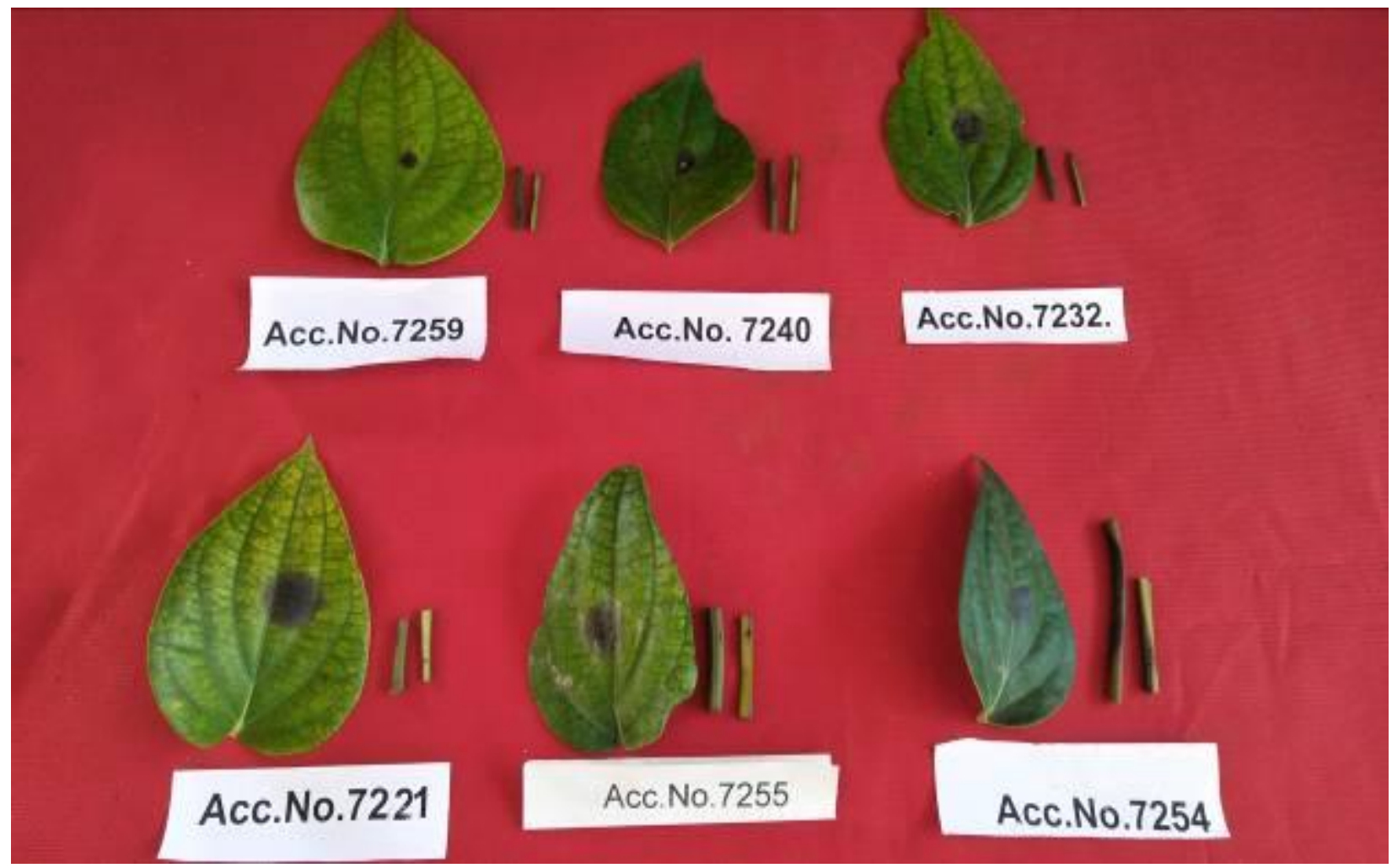

In conclusion, screening of 20 selected black pepper accessions of the germplasm in comparison with the check variety Panniyur 5 was carried out through artificial inoculation by Phytophthora capsici, following stem and leaf inoculation technique under controlled greenhouse ambience .The experiment showed that neither of the accessions or check variety as resistant to foot rot. However the accession 7259 had expressed moderate resistance with an overall mean DSI of $39.44 \%$ which can be further assayed for root infection in the field.

\section{Acknowledgement}

The first author is greatly indebted to the Director, ICAR-IISR for granting study leave and the Kerala Agricultural University for the $\mathrm{PhD}$ programme for evolving this paper as part of the doctoral research.

\section{References}

Anonymous, 1977. Ghana-a potential producer of pepper. Pepper News 1 (2): 4-5.

Anandaraj. M., Jose, A. and Balakrishnan, R .1989. Crop loss due to foot rot disease of black pepper. Indian Phytopathol. 42: 473 - 476.

Bhai, R. S., Anandaraj, M., Sarma, Y. R., Veena, S. S., and Saji, K.V. 2007. Screening of black pepper (Piper nigrum L.) germplasm for resistance to foot rot disease caused by Phytophthora capsici Leon. J. Spices and Aromatic. Crops. 16(2): 115-117.

DeWaard, P.W.F. (1979). Evaluation of the results of research on eradication of Phytophthora foot rot of black pepper (Piper nigrum L.) pp.1-47. Circulated during the first meeting of the pepper community permanent panel on techno 
economic studies, 31-January-4 February, 1979. Cochin, India.

Divya, C. R. and Sharada, M. S. 2014. Screening of Piper nigrum $v$ arieties/cultivars against quick wilt caused by Phytophthora capsici Leon. Under green house condition. Int. J. Recent Sci. Res. 5(11): 2028-2030.

Eikemo, H., Stensvand, D. J. and Tronsmo, A. M. 2003. Resistance to crown rot (Phytophthora cactorum) in raspberry cultivars and in offspring from crosses between cultivars differing in susceptibility to the disease Ann. Appl. Biol. 142: 83-89.

Kim, K.Y., Park, S. K., Shin, Y. A., and Lee, E. J. 1990. Survey on the actual condition of cultural methods and continuous cultivation injury of red pepper in field. Research Reports of the Rural Development Administration, Horticulture. 32: 1-10.

Mammootty, K. P., Abraham, K. and Vijayaraghavan, R. 2008. Screening black pepper (Piper nigrum L.) varieties/cultivars against Phytophthora disease in nursery. J. Tropical Agri. 46(1-2):70-72.

Nguyen,V. L. 2015. Spread of Phytophthora capsici in Black Pepper (Piper nigrum) in Vietnam. Engineering. (7): 506 - 513.

Sarma Y. R., Nambiar K. K. N. 1979. Screening of pepper (Piper nigrum L.) against Phytophthora palmivora. In: Venkataram C S (Ed.) Proc. PLACROSYM-II 1979 (pp. 403-406). Indian Society for Plantation Crops, Kasaragod.

Sarma Y. R, Nambiar K. K. N. and Nair, M. K. 1982. Screening of black pepper (Piper nigrum L) and Piper species against Phytophthora palmivora. In: Nambiar K. K. N. (Ed.), Proc. Workshop on Phytophthora Diseases of Tropical Cultivated Plants (pp. 242247). Central Plantation Crops Research Institute, Kasaragod.

\section{How to cite this article:}

Prakash, K.M., R.S. Bhai, J. Jiji, K.V. Saji, V.S. Sujatha and Santhoshkumar, A.V. 2019. Exploitation of Resistant Sources to Phytophthora capsici Leon. from Genetic Stocks of Black Pepper (Piper nigrum L.). Int.J.Curr.Microbiol.App.Sci. 8(05): 1487-1496.

doi: https://doi.org/10.20546/ijcmas.2019.805.171 